\title{
6
}

\section{Knowledge, Research, and Germany's Bioeconomy: Inclusion and Exclusion in Bioenergy Funding Policies}

\author{
Rosa Lehmann
}

\subsection{Introduction: Bioenergy's Uncertain Prospects}

The future of Germany's bioenergy is unclear. Bioenergy is commonly associated with rapeseed and corn monocultures, and with wood chip heating or biogas plants, which turn either scrap wood or cow manure and cultivated biomass into electricity and heating, respectively. The research into bioenergy production by private farmers or (and this is particularly the case in Germany) bioenergy cooperatives has a firm place in the growing body of social science literature on the global energy transition. These citizen-based renewable energy projects serve as examples of a decentralized energy transition, i.e. a transition where energy is produced and consumed not centrally but in the rural areas or the neighbourhoods in which it is produced. This anchors the energy transition socially and contributes to its success (see Kunze 2012; Morris

\section{R. Lehmann $(\varangle)$}

Institute of Sociology, Friedrich Schiller University Jena, Jena, Germany e-mail: rosa.lehmann@uni-jena.de 
and Jungjohann 2016; Radtke 2016). In studies that explicitly adopt an energy justice perspective (Jenkins et al. 2016), these models increase participation and benefit-sharing due to ownership structures that enable a broader scale of involvement than is possible with large private stock companies (e.g. Kunze 2012; Szulecki 2018). ${ }^{1}$ Although different studies and experts predict the survival of bioenergy production (see Szarka et al. 2017; Strzalka et al. 2017), recent research reveals that the social dimension of bioenergy production as described above is facing uncertainties concerning regulatory and technological developments, such as the expiration of subsidies and the need for the flexibilization of biogas plants (Backhouse et al. 2020).

Discussions about the technological aspect of bioenergy in the energy transition centre on bioenergy technology and innovative biomass. The future of the energy system is said to rely on "the artificial leaf" in terms of artificial photosynthesis (Marshall 2014), on algae and other microorganisms in energy generation, e.g. on building walls, or fuels produced from straw residues and cup plants, with the latter turning erosion-prone slopes into flourishing, bee-friendly landscapes. ${ }^{2}$ One starts to imagine algae tanks on the roofs of public libraries and futuristic artificial bushes replacing green-white biogas plants. Nevertheless, the social dimension of these technological visions is somewhat blurred.

The German Bioeconomy Strategy began with the publication of a document in 2010 by the Federal Ministry of Education and Research (BMBF 2010). The Bioeconomy Strategy is focused on future technologies and research and innovation (R\&I) and constitutes a puzzle for the attempt to assess the prospects of bioenergy and, most notably, its social dimension. Research in science and technology studies (STS) and political ecology has shown that the use of a resource or technology (for energy production) reshapes social relations (see Görg 2004;

\footnotetext{
${ }^{1}$ It is noteworthy that "civil society" is neither a homogenous actor, nor are these models $100 \%$ inclusive (see Radtke 2016).

${ }^{2}$ See, e.g., the recommendation of the German Bioeconomy Council (German Bioeconomy Council 2016) or the contributions on the website https://www.pflanzenforschung.de, which represent findings of research funded by the Federal Ministry of Education and Research $(\mathrm{BMBF})$ on applied plant research.
} 
Huber 2015; Lohmann and Hildyard 2014; Miller et al. 2013). Consequently, I understand energy systems as socio-technical systems that not only comprise technology and raw materials, but also human labour, economic investments, institutions, norms, narratives, and power asymmetries between unequally included social groups (Miller et al., p. 136). Thus, I refer to the concept of socio-energy systems in this contribution.

Bioenergy played a role in the Bioeconomy Strategy until 2019. The strategy supports research into the material, chemical, and energetic use of biomass and biological knowledge in order to fundamentally transform the economy. It is embedded in the High-Tech Strategy and in different sustainability and energy policies (see Meyer 2017) and further claims to encompass not only the technological but also the social aspects of the transformation towards a bio-based economy (Fraunhofer ISI 2017, p. 7; BMBF and BMEL 2014; BMBF 2010, 2014; BMEL 2014). However, bearing in mind the importance of decentralized citizen-based bioenergy production for dynamics of the German energy transition, how can we interpret bioenergy-related R\&I in the bioeconomy and the associated predictions relating to bioenergy technology? To answer this question, I focus on the Bioeconomy Strategy to deduce the role of bioenergy in R\&I and ask how and to what extent bioenergy is related to the production of knowledge in the German strategy. Whose and what kind of knowledge about energy production is supported in funding policies? However, it is also important to understand who and what are excluded when it comes to the social dimension of the current technology-driven bioeconomy (see Birch et al. 2010) as well as for debates about justice in future socio-energy systems.

For the analysis of inclusions and exclusions, I am guided by the proposal of Miller et al. (2013, pp. 136-137) to structure research on energy transitions along the lines of the following analytical categories: energy infrastructures, energy epistemics, and energy justice. I focus on inequalities related to R\&I, hence on the latter two categories. I argue that unequal energy epistemics are reflected in the gap between technology-laden research and existing social practices of bioenergy production. The focus of bioeconomy-related R\&I is on high-technology

\footnotetext{
${ }^{3}$ Federal Ministry of Food and Agriculture.
} 
innovation and tends to neglect existing experiences and practices of different actors in the bioenergy sector. However, it would be crucial to take the history of socio-(bio)energy systems into account for further biomass-centred strategies that encompass, at least rhetorically, the social dimension of a transition to a bioeconomy.

The research perspective taken here may seem surprising. Technical, governance, and sustainability studies on bioenergy exist for the European context (e.g. Bentsen et al. 2019; Lewandowski 2015; Szarka et al. 2017). Social science research on bioeconomy examines bioenergy in terms of biomass production, sustainability issues, and policies (e.g. Toivanen in this volume) or assesses the perspective of politicalinstitutional changes or/and narratives in the bioeconomy (e.g. Goven and Pavone 2014; Giurca 2018). The shape of R\&I in the German Bioeconomy Strategy has been discussed in general assessments (Priefer et al. 2017). STS studies emphasize that an analysis of R\&I funding is key to understanding inclusions and exclusions regarding knowledge production (e.g. Frickel et al. 2010; Tyfield et al. 2017). Energy justice literature stresses this dimension for the analysis of renewable energies, although knowledge production is but one category in related research. This chapter contributes to these research fields by examining the shape of bioenergy-related R\&I within bioeconomy policies in Germany. It is based on the analysis of grey literature: position papers and press releases, protocols of stakeholder meetings, web pages, press articles, policy and strategy papers, and evaluation reports published by federal ministries and research institutions. Findings are complemented with insights from ten qualitative expert-interviews. The structure is as follows: Sect. 6.2 sketches the analytical framework, Sect. 6.3 presents the preliminary results, and Sect. 6.4 discusses further research.

\subsection{Approaching Bioenergy: Epistemics and Justice}

As studies on historical and the current energy transition(s) reveal (e.g. Mitchell 2009; Elmhirst et al. 2017), energy systems are inextricably linked to, form, and confine the (unequal) structure of society; hence, 
they are restructured by changes in the energy system (Miller et al. 2013, p. 136; also Lohmann and Hildyard 2014). Therefore, I refer to them as socio-energy systems. To different extents, research on the social dimension of energy considers the role of knowledge production and the resources actors dispose of to generate expertise and innovation and to promote its realization (historically: Malm 2016). In their introductory article to a journal issue on energy transitions, Miller et al. (2013, pp. 136-137) explicitly apply the role of knowledge production to the exploration of corresponding power relations and inequalities and suggest analysis of energy infrastructures, energy epistemics, and energy justice. In order to examine inclusions and exclusions in bioenergy-related funding policies, the latter two categories are of greater importance for this contribution. Energy epistemics, simply put, is about " $[\mathrm{w}]$ ho knows about energy systems, what and how do they know, and whose knowledge counts in governing and reshaping energy futures?" (ibid., p. 137). Studies on energy epistemics and related policies (e.g. Hess and McKane 2017) resonate with findings on knowledge production and inequalities. Along this line, Frickel et al. (2010, p. 467) stress that power relations between actors with different resources shape research priorities and exclude antagonist ideas to a large extent:

scientific research is increasingly complex, technology-laden, and expensive, [therefore] there is a systematic tendency for knowledge production to rest on the cultural assumptions and material interests of privileged groups. (ibid., p. 446)

Research into the issues that social movements, affected residents, and non-governmental organizations consider important has been, to a lesser degree, funded and completed (ibid.). These include health issues as a consequence of industrial emissions or the use of pesticides in agroindustry (see Arancibia and Motta 2018; Toledo López in this volume). Following Tyfield et al. (2017, pp. 1-9), this is due to the dominant social notion of knowledge as a growing array of "factual, normatively neutral truths" (ibid., p. 2) that result in economic growth. Tyfield et al. claim that the concomitant fetishism of high-technology and research-intensive innovation also applies to research into climate change 
mitigation and into sustainable substitutes to fossil raw materials (ibid., p. 10). Hence, actors that question this assumption or at least try to balance social and environmental issues with economic concerns are in a less powerful position from the outset. Social scientific research into the bioeconomy confirms that narratives of economic growth dominate over those of nature protection and ecological limits (see Birch et al. 2010; Kleinschmit et al. 2017; Vivien et al. 2019) and that bioeconomy strategies reveal an imbalance through the inclusion of different social groups during agenda setting (e.g. Lühmann 2020; Tittor in this volume).

Energy justice serves as a concept to assess the inclusions and exclusions surrounding energy infrastructures and epistemics. Although grid connections and clean cooking fuels are important when tackling energy poverty and its social and health impacts, as are financial contributions for renewables in attempts to mitigate climate change, energy justice goes beyond these issues to "[s]imply decarbonizing the status quo" (Healy and Barry 2017, p. 457). Due to their materiality, renewables have the potential to be produced, distributed, and consumed in a decentralized energy system (Malm 2016, pp. 37-42). At the same time, they can redistribute ownership and decision-making to different actors, which could prevent the concentration of capital and enable the development of democratized socio-energy systems (Wissen 2016, p. 57). Summing up the energy justice debate, Kirsten Jenkins et al. (2016) put the distributional, recognition-based, and procedural aspects of energy production, distribution, and consumption centre stage: energy justice is aimed at achieving the comprehensive inclusion of actors affected along the value chain (also Avila-Calero 2018; Becker and Naumann 2017; Szulecki 2018; Weis et al. 2015). Here, the equal distribution of costs and benefits is as important as respecting and recognizing the concerns that locals may have about energy projects. Procedural justice refers to transparency and information, equal representation, and the participation of different groups in decision-making. Further, it comprises the role of knowledge of different actors, notably of affected citizens. In the literature, this is often related to Indigenous knowledge. In this chapter, I apply these thoughts to the prospects for bioenergy and current bioenergy-related research in the bioeconomy and argue that (e.g. practitioners', civil society activists') knowledge about decentralized bioenergy production is included in or on 
the agenda of innovation-driven, research-oriented R\&I to much lesser extent.

In sum: inequalities in R\&I are of importance for the analysis of transitioning socio-energy systems. A perspective that builds on energy epistemics and justice enables not only the examination of inclusions and exclusions in bioenergy-related knowledge production in the bioeconomy but the possibility of mooting ideas about the social dimension of the energy transition. In the following section, I assess the shape of bioenergy-related R\&I in the German bioeconomy.

\subsection{Bioenergy in the Transitioning Landscape of the German Bioeconomy: Empirical Insights}

Although the focus of this contribution lies on inclusions and exclusions in energy epistemics, existing bioenergy-infrastructures and their role in the current energy transition are of importance for debating and evaluating the character of bioenergy-related R\&I in the bioeconomy. They are particularly important for describing the status quo of the production, distribution, and consumption of bioenergy as well as for sketching the positions of bioenergy actors in debates. Thus, the following section presents some data on bioenergy in Germany. In Sect. 6.3.2 and 6.3.3, I explore the relationship of bioenergy and R\&I in the German Bioeconomy Strategy.

\subsubsection{The Socio-Energy Nexus in Germany's Transition Towards Renewable Energies}

Legal regulation has led to a boom in the energy transition in Germany: with the implementation of the 1990 feed-in law (Stromeinspeisegesetz) and, notably, the 2000 Renewable Energies Act (EEG), the share of renewables in gross electricity consumption increased from $3.4 \%$ in 1990 to $37.8 \%$ in 2018, and the share of end consumption for heating rose from $2.1 \%$ to $13.9 \%$, and in the transport sector from 
$0.1 \%$ to $5.6 \%$ during the same period (see BMWi-Federal Ministry for Economic Affairs and Energy 2019, pp. 4-5). Biomass-based energy produced by farmers and operators of bioenergy plants using cultivated biomass (including wood), cow manure, and other waste and residues plays a part in this renewable energy scenario. The Renewable Energy Agency refers to bioenergy as the "all-rounder" 4 amongst the renewables, although its share in the energy mix is decreasing in Germany: in 2019, bioelectricity, which is mostly produced in biogas plants in Germany, accounted for about $8.7 \%$ of total gross electricity consumption (UBAFederal Environment Agency 2020). In the heating sector, biomass-based energy (notably from wood) makes up for $86 \%$ and is the most important renewable in the sector. Renewable fuels (biodiesel, bioethanol, biomethane) have been constant at around 5.6\%, although the share of electricity-based fuels has increased recently (see ibid.; FNR-Fachagentur nachwachsende Rohstoffe 2019). Changes in the EEG (2012 and 2014) restricted the yearly extension of bioelectricity to 0.1 Gigawatt (GW; for comparison: Photovoltaic: 2.5 GW), to the discontent of many bioenergy producers (Haas 2017, pp. 64-210). Most of this power was produced from waste and residues. The growth of bioenergy production and consumption has been accompanied by controversy about monocultures, rising land prices and competition between biomass production for food, fodder, and energy (see 6.3.2). This has led to contestation over sustainability policies for bioenergy and, amongst others, calls for investment in bioenergy produced using waste, residues, and microorganisms. ${ }^{5}$

Concerning actor constellations and ownership structures of the transitioning energy system, the German Energiewende was born out of the struggles of social movements against nuclear power and for environmental protection as well as of efforts by pioneering citizens and small enterprises that invested in and experimented with renewable technologies. A large percentage of renewable energy continues to be produced by

\footnotetext{
${ }^{4}$ See, https://www.unendlich-viel-energie.de/erneuerbare-energie/bioenergie. Accessed 3 Feb 2020.

${ }^{5}$ See, https://biooekonomie.de/nachrichten/industrie-setzt-auf-bioenergie-der-zweiten-generation. Accessed 12 April 2020.
} 
small-scale producers, be it private farmers, building owners, or citizenbased energy projects (for a comprehensive overview, see Kahla 2018). Bioenergy is part of the product range provided by energy cooperatives, mostly for consumption in the (rural) region in which it is produced (this especially applies to electricity and heating, but also to fuel, e.g. for agricultural vehicles). Bioenergy villages and regions, which are locations where citizens consume energy generated from local resources in plants and facilities owned by cooperatives or by private residents, have been promoted by governments to enlarge income opportunities for agricultural production and forestry, advance rural livelihoods and support acceptance of the energy transition, and ensure that it becomes anchored within society (see Hirschl et al. 2010; Kunze 2012). Recently, local heating networks based on renewables have begun to gain in importance, since the heating sector now accounts for around $50 \%$ of the energy demand (Beer et al. 2018, pp. 74-76).

In sum, bioenergy in Germany ranges from (large-)scale and ecologically problematic monocultures to the use of waste and residues, and from large biogas plants to small facilities that particularly generate electricity and heat, and which are often based on models of citizen participation. This social dimension of bioenergy infrastructure is important for debates about the decentralization and democratic design of the energy system as well as about the bioeconomy's aim to use biomass for it illustrates how transformation strategies such as the bioeconomy can be anchored in society. I now turn to bioenergy epistemics in the German bioeconomy, arguing that it neglects these aspects.

\subsubsection{Bioenergy Epistemics: Funding of Knowledge Production and Narratives}

In Germany, energy research includes energy conversion, storage systems and energy efficiency, institutional energy, and nuclear security. Funding of applied research into (bio)energy applications for specific projects is undertaken under the lead of the $\mathrm{BMWi}$, whereas basic research is the responsibility of the BMBF (BMWi 2018a, b). In the National Research Strategy Bioeconomy 2030 (NRS) (BMBF 2010), which was 
launched by the BMBF, bioenergy is the least funded "field of action" (FoA). Until 2016, FoA 5 (Developing biomass-based energy carriers) received just $2.6 \%$ of funds (22 million euros; in contrast, research on renewable resources for industry received $23.7 \%$ or 204.6 million euros) (Fraunhofer ISI 2017, pp. 3-5). ${ }^{6}$ Bioenergy-related research has been undertaken in other areas under the responsibility of the BMEL, the $\mathrm{BMBF}$, and the BMWi (ibid.). However, it is irritating that although documents relating to the Bioeconomy Strategy list projects funded by these ministries, other documents produced by the BMWi on bioenergy research pay little or no attention to the Bioeconomy Strategy (e.g. BMWi 2011, 2018a, b). ${ }^{7}$ The minor role of bioenergy played here is a reflection of the decreasing importance of the one-to-one substitution of fossil energy resources by biomass-based ones within bioeconomy strategies (Vivien et al. 2019, pp. 192-193). Instead, the focus is increasingly on cascade use and by-products (e.g. BMEL 2016, pp. 75-76).

Experts suggest two reasons for this: first, the biotechnology sector has predominantly pushed the bioeconomy (Grefe 2016) and the German as well as the EU strategy (EU 2007) are successors of biotechnology policies (Fraunhofer ISI 2017, p. 1; Lühmann 2020), with the latter having provided the impulse for the former (Kleinschmit et al. 2017, p. 5). Like other strategies focusing on the advanced use of biomass and the involvement of different economic sectors (Vivien et al. 2019), the German strategy stands "in the tradition of past expectations of biotechnology" and expands "the promises of economic growth to traditional sectors of the bioeconomy" (Meyer 2017, p. 7). Bioenergy has the lowest added value, and despite public funding and incentives, research on and the production of bioenergy exist under market conditions; hence, bioenergy has to compete with fossil fuels and the well-established production chains associated with petrochemicals, which are obstacles to bio-based products with higher value generation (ibid., pp. 17-18). Further, bioenergy also faces competition from various renewable energy options and from different sectors of the bioeconomy that are dependent on biomass

\footnotetext{
636 funding measures were accepted under the umbrella of the BMBF alone, and 1,800 projects were funded between 2009 and 2016 with 876 million euros (Fraunhofer ISI 2017, p. 1).

${ }^{7}$ Further research should engage with these deviating perceptions on the importance of the Bioeconomy Strategy in the state apparatus, possibly reflecting competing resort responsibilities.
} 
(ibid., p. 23). The role of bioenergy in the future energy system will depend on technological innovation that enables multi-purpose and upgraded agriculture and forestry and, therefore, higher value generation, as this provides new fields for capital accumulation. Research is thus focused on the application maturity of products and innovative technologies, and on its capital- and research-intensive forms, in particular. This applies not only to a "technic-centred understanding of innovations" (ibid., p. 9; Backhouse et al. 2017) but also to the future trajectory of the energy transition. In the case of bioenergy, innovation exists and research is funded in areas such as the flexibilization of biogas plants, as well as into biomethane production and cogeneration plants (see DUH-Deutsche Umwelthilfe 2018), and, as part of the Bioeconomy Strategy, into the use of frugal energy plants, waste, and residues (e.g. BMEL 2016, pp. 59, 68). However, when describing biogas, an expert argued that biogas was an "old hat" that provided no "new technology, no new approach, and thus it is not of real political value" (Institute for Biogas, Interview no. 1, own translation) in contrast to, e.g. powerto-gas-plants. Hence, in this view, other energy sources can be politically promoted much better as innovative enough to meet the energy demands of a post-fossil Germany.

This character of the bioeconomy is driven by the focus on new technologies which promises to secure both the status quo of resource consumption and environmental protection (see Birch et al. 2010). It is reflected in the funding of projects that use algae for bio-kerosene for aviation and straw for biofuel (in cooperation with leading stock companies such as Airbus Group, OMV, and Clariant AG). The Recommendations of the German Bioeconomy Council for energy in the bioeconomy do not even mention the word "biomass" in the relevant paragraph on the "Conversion and storage of solar energy, hybrid energy systems" (German Bioeconomy Council 2016, p. 16), which, instead, focuses on artificial photosynthesis and solar-based energy production. The accompanying narrative to this focus on high-technology innovation is based on perspectives linked to Germany as an industrial location for technology leadership and international competitiveness (Fraunhofer ISI 2017, p. 1; BMEL 2016, p. 68; German Bioeconomy Council 2016, 
p. 11); it also reflects Germany's political economy as an export-driven regime of accumulation (see Haas 2017, pp. 146-154).

Secondly, experts from the bioenergy sector assume that the food-orfuel-debate that has taken place during the past two decades has led (amongst other factors concerning the economic efficiency of bioenergy) to legal changes in areas including the regulation of the use of renewable cultivated biomass such as corn (Beer et al. 2018, p. 75). This debate revolves around the argument that the use of agricultural or forest lands for the cultivation of energy crops triggers competition between food, feed, or fodder production and, frequently, leads to negative socioecological impacts (see Evia Bertullo 2018; Lewandowski 2015). Press articles, blog contributions, as well as recent qualitative interviews by the author of this contribution reveal that actors in the bioenergy sector such as biogas producers, employees of state agencies, and consultants consider this critique of bioenergy as unfair as it conceals the technological and ecological progress that has been achieved in the sector. Although comprehensive studies into the influence of this debate on bioeconomy policies are a lacuna, Meyer suggests that the controversies surrounding first generation biofuels could be germane to the "aspired transformation towards a bio-based industry” (Meyer 2017, p. 23). If it is mentioned in the bioeconomy context, bioenergy research is framed as sustainable, rural development and a commitment to food-first, although the latter has yet to be proven (ibid., p. 23; see also Bringezu et al. 2020).

\subsubsection{Bioenergy Justice: R\&I Innovations and Societal Participation}

Civil society actors have concentrated on the development of the exclusive research agendas within the Bioeconomy Strategies from the start. They argue that a reliance on old and "antiquated" (BUND, Interview no. 2, own translation; also Meyer 2017, pp. 16-17) structures and networks of interest intermediation between state agencies, private economic actors, and scientists in Germany (see Brandl 2018) has frequently led to the exclusion of civil society actors (e.g. Grefe 2016; Zivilgesellschaftliche Plattform Forschungswende 2017). In the wake 
of this criticism, the composition of the expert German Bioeconomy Council, which mostly consists of scientific experts from the biotechnology and chemical industry, slightly changed and stakeholder workshops have increasingly included critical NGOs and experts. However, the Council continues to be dominated by (non-organic) agricultural and consumer associations and the biotech and chemistry industry. Further, although a significant number of environmental NGOs and organic farmers' associations have participated in events run by government institutions that explicitly address issues like an environmental friendly agriculture or biodiversity protection, ${ }^{8}$ "dialogue" is limited to these formats; as such, no structured funding exists for critical NGOs to engage with complex bioeconomy-related issues or to set up R\&I agendas and compete politically with the private sector (see Zivilgesellschaftliches Aktionsforum Bioökonomie 2019).

The inclusion of critical or alternative research in the bioeconomy predominantly concerns agriculture, with a notable concentration on agroecological practices (Meyer 2017, p. 22; see Levidow et al. 2012). However, in line with the minor involvement of NGOs and other civil society-based associations, collective knowledge about energy issues and practices of societal control of and participation in renewable energy projects by energy cooperatives and energy justice activists is scarcely included in the bioenergy-related research that is conducted within the bioeconomy context. Only one event listed in past funding activities on bioeconomy stakeholder meetings explicitly addresses some of these actor groups: the "Congress Bioenergy Villages" (Kongress Bioenergiedörfer) that took place in March 2014 (Bundesregierung 2017, p. 12). Although similar events are financed by other state programmes and agencies, this demonstrates that the experiences of these actors do not shape the bioeconomy agenda.

In the light of the character of bioenergy epistemics in the bioeconomy, one could argue that the promise that in the case of citizen-based bioenergy production R\&I will lead to the same extent

\footnotetext{
${ }^{8}$ Unions did not participate in either of these events (Bundesregierung 2017, p. 10-15), although the dominant form of the bioeconomy and the specific mode of value creation will reproduce and create different kinds of jobs, varying in terms of work relations, work locations (urban, rural), or requested education (Braun and Brandl 2016; see Lorenzen in this volume).
} 
of economic growth as other forms of research on bioeconomytechnoscience have not been kept. These models are provided with some funding as part of BMWi's energy policies, with emphasis on the digitalization of energy production, distribution, and consumption. In addition, in electricity and heating, which is the concern of federal, regional, and local policy-making, practices of decentralized structures exist that also receive political support (Beer et al. 2018, pp. 68-70, 76-77). An energy justice perspective could apply these experiences of the decentralized control of important utilities (energy) when dealing with current and future developments related to more advanced biomass-based products.

However, R\&I related to bio-based chemicals, products, and energy technology is, as Frickel et al. (2010, p. 467) state when referring to technoscience in general, "increasingly complex, technology-laden, and expensive". Studies of bioenergy cooperatives as well as recent interviews with experts in the field show that the complexity of technology, administration, and organization of (cooperative) bioenergy production facilities leads to the automatic exclusion of cooperative members or farmers who lack the time and knowledge to hold pace with technological and regulatory advancements (see Backhouse et al. 2020). Although the German Bioeconomy Strategy is celebrating its tenth anniversary, qualitative research for this chapter shows that experts and practitioners from the bioenergy sector have, at best, a vague understanding of the bioeconomy pushed by the federal government. Interviews showed that, the sector is focused on the expiration of subsidies for biogas plants, wood carburettors and wood chip heating, as well as unstable energy transition regulations and environmental laws like the recent decree on liquid manure, which implies investment for stock farmers. The question of how further R\&I in the bioenergy-related field of the bioeconomy-innovation-driven, technology-laden-reproduces or advances this tendency, or if broader sectors of society are included in distributional, recognition-based, and procedural aspects of future (bio)energy questions, remains open. 


\subsection{Conclusion}

In this chapter, I examined inclusions and exclusions in bioenergy-related research funding activities in the German Federal Government's first Bioeconomy Strategy against the backdrop of theoretical concepts that stress power relations and inequalities in energy transition politics as well as knowledge production. I adopted the perspective of energy justice research and focused on knowledge production in bioenergy. Moreover, I particularly focused on the role of decentralized energy production practices, since it is these social forms that enhance inclusion and partly enabled the development of the German energy transition. I asked how and to what extent bioenergy is related to the production of R\&I in the Bioeconomy Strategy and the kind of knowledge about energy production that is supported by funding strategies; the aim was to assess the prospects of the social side of bioenergy in future socio-energy systems as well as in the bioeconomy.

Findings show that unequal energy epistemics are reflected in the fissure between technology-laden research and existing practices of bioenergy production. Bioeconomy research into bioenergy reveals the constricted perception of innovation and the assumption that R\&I has to engender economic growth. Existing practices of different actors in the bioenergy field tend not to be taken into account by those who design the bioeconomy agenda. A structured exchange is still lacking; this applies to the Bioeconomy Strategy in general, as well as to bioeconomyrelated bioenergy policies specifically. The different social experiences that have been made with renewable (bio)energy in Germany provide an opportunity not only to broaden the spectrum of stakeholder discussions and funding schemes but also to engender structural change that could set the framework with which to reshape the character and goals of research within the bioeconomy, which, until now, has been rather exclusive and technology-laden. Given the contention surrounding planned renewable energy infrastructures, the inclusion of more actors and a broader perspective on innovation and its use for society would open the door for discussions about just transitions-this applies to both socio-energy systems and the resource basis of current economies. The extent and regard to which civil society-based bioenergy production 
models will be included or include themselves in (discussions about) bioenergy-related bioeconomy policies and whether the idea of decentralized, democratized energy systems can be integrated or combined with an increasingly technology-laden and digitalized production, distribution, and consumption of energy are of further interest.

The draft and final version of the new Bioeconomy Strategy, which passed cabinet in January 2020 (BMBF and BMEL 2019, 2020), resonates the need for research into a broader spectrum of bioeconomic practices and knowledge, including studies of environmental or development impacts, and resource competition. The way in which this will be realized deserves to be a focus of research in the years to come.

\section{List of Interviews quoted}

\begin{tabular}{lll}
\hline Expert interview no. & Institution; Organization & Date and place \\
\hline Expert interview no. 1 & $\begin{array}{l}\text { Institute for Biogas, Waste } \\
\text { Management and Energy }\end{array}$ & $\begin{array}{c}16 \text { January 2020, } \\
\text { Weimar }\end{array}$ \\
Expert interview no. 2 & $\begin{array}{c}\text { NABU (Nature And } \\
\text { Biodiversity Conservation } \\
\text { Union) }\end{array}$ & $\begin{array}{c}17 \text { October 2019, } \\
\text { Berlin }\end{array}$ \\
\hline
\end{tabular}

\section{References}

Arancibia, F., \& Motta, R. (2018). Undone Science and Counter-Expertise: Fighting for Justice in an Argentine Community Contaminated by Pesticides. Science as Culture, 28(3), 277-302.

Avila, S. (2018). Environmental Justice and the Expanding Geography of Wind Power Conflicts. Sustainability Science, 13(3), 599-616.

Backhouse, M., Lorenzen, K., Lühmann, M., Puder, J., Rodríguez, F., \& Tittor, A. (2017). Bioökonomie-Strategien im Vergleich. Gemeinsamkeiten, Widersprüche und Leerstellen. Working Paper 1, Bioeconomy \& Inequalities, Jena. https://www.bioinequalities.uni-jena.de/sozbemedia/neu/2017-09-28+ workingpaper+1.pdf. Accessed 14 Nov 2019.

Backhouse, M., Büttner, M., Greifenberg, D., Herdlitschka, T., Lehmann, R., Schaller, E., et al. (2020). Erneuerbare Energien von unten? Perspektiven 
aus der Praxis auf dezentrale Energiesysteme. Working Paper 14, Bioeconomy \& Inequalities, Jena. https://www.bioinequalities.uni-jena.de/sozbem edia/wp/workingpaper14.pdf. Accessed 10 June 2020.

Becker, S., \& Naumann, M. (2017). Energy Democracy: Mapping the Debate on Energy Alternatives. Geography Compass, 11(8), 1-13.

Bentsen, N.S., Larsen, S., \& Stupak, I. (2019). Sustainability Governance of the Danish Bioeconomy-The Case of Bioenergy and Biomaterials from Agriculture. Energy, Sustainability and Society, 9(40).

Beer, K., Böcher, M., Bollmann, A., Töller, A.E., \& Vogelpohl, T. (2018). Arbeitsbericht 1. Fallauswahl und Übersichtsanalysen. Verbundprojekt Politische Prozesse der Bioökonomie zwischen Ökonomie und Ökologie. http:// www.bio-oekopoli.de/bio-oekopoli/download/arbeitspapier_1.pdf. Accessed 14 Nov 2019.

Birch, K., Levidow, L., \& Papaioannou, T. (2010). Sustainable Capital? The Neoliberalization of Nature and Knowledge in the European "KnowledgeBased Bio-economy". Sustainability, 2, 2898-2918.

BMBF (2010). National Research Strategy BioEconomy 2030. Our Route towards a biobased economy. Bonn. https://www.pflanzenforschung.de/application/ files/4415/7355/9025/German_bioeconomy_Strategy_2030.pdf. Accessed 5 Nov 2020.

BMBF (2014). Wegweiser Bioökonomie. Forschung für biobasiertes und nachhaltiges Wirtschaftswachstum. Berlin. https://biooekonomie.de/sites/default/ files/publications/wegweiser-biooekonomiepropertypdfbereichbiooekosprac hederwbtrue.pdf. Accessed 5 Nov 2020.

BMBF \& BMEL (2014). Bioeconomy in Germany. Opportunities for a Bio-based and Sustainable Future. Bonn, Berlin. https://www.bmbf.de/upload_filest ore/pub/Biooekonomie_in_Deutschland_Eng.pdf. Accessed Nov 232020.

BMBF \& BMEL (2019). Nationale Bioökonomiestrategie. 2 July 2019 ENTWURF. https://www.raiffeisen.de/sites/default/files/2019-07/201907-02_Nationale\%20Bio\%C3\%B6konomiestrategie.pdf. Accessed 30 Sep 2019.

BMBF \& BMEL (2020). National Bioeconomy Strategy. Berlin. https://www. bmbf.de/upload_filestore/pub/BMBF_Nationale_Biooekonomiestrategie_ Langfassung_eng.pdf. Accessed 19 Oct 2020.

BMEL (2014). Nationale Politikstrategie Bioökonomie. Berlin. https://bio oekonomie.de/sites/default/files/publications/npsb_0.pdf. Accessed 5 Nov 2020.

BMEL (2016). Fortschrittsbericht zur Nationalen Politikstrategie Bioökonomie. Berlin. https://www.bmel.de/SharedDocs/Downloads/DE/Broschueren/For 
tschrittsbericht-Biooekonomie.pdf?_blob=publicationFile\&v=2. Accessed 5 Nov 2020.

BMWi (2011). Forschung für eine umweltschonende, zuverlässige und bezahlbare Energieversorgung. Das 6. Energieforschungsprogramm der Bundesregierung. Berlin. https://www.bmwi.de/Redaktion/DE/Publikati onen/Energie/6-energieforschungsprogramm-der-bundesregierung.pdf? blob $=$ publicationFile\&v=12. Accessed 5 Nov 2020.

BMWi (2018a). 2018 Federal Government Report on Energy Research. Funding Research for the Energy Transition. Berlin. https://www.bmwi.de/Redaktion/ EN/Publikationen/Energie/bundesbericht-energieforschung-2018.pdf? blob=publicationFile\&v=5. Accessed 5 Nov 2020.

BMWi (2018b). Innovationen für die Energiewende. 7. Energieforschungsrahmenprogramm der Bundesregierung. Berlin. https://www.bmwi.de/Redakt ion/DE/Publikationen/Energie/7-energieforschungsprogramm-der-bundes regierung.pdf?_blob=publicationFile\&v=4. Accessed 5 Nov 2020.

BMWi (2019). Zeitreihen zur Entwicklung der erneuerbaren Energien in Deutschland. Berlin. https://www.erneuerbare-energien.de/EE/Redaktion/ DE/Downloads/zeitreihen-zur-entwicklung-der-erneuerbaren-energien-indeutschland-1990-2019.pdf;jsessionid=89DA6B4D4C703767C26DF375 99690377? _blob=publicationFile\&v=26. Accessed 18 Jan 2020.

Brandl, B. (2018). Wissenschaft, Technologieentwicklung und die Spielarten des Kapitalismus. Analyse der Entwicklung von Saatgut in USA und Deutschland. Wiesbaden: Springer VS.

Braun, V., \& Brandl, B. (2016). Von der Kommodifizierung zur Refeudalisierung? Wertschöpfung in der Bioökonomie. Beitrag zur Veranstaltung ,Bioökonomie. Grenzen des Wachstums oder Füllhorn Natur?' Sektion Land- und Agrarsoziologie der Deutschen Gesellschaft für Soziologie.

Bringezu, S., Banse, M., Ahmann, L., Bezama, A., Billig, E., Bischof, R., et al. (2020). Pilotbericht zum Monitoring der deutschen Bioökonomie. Universität Kassel, Center for Environmental Systems Research (CESR). https:// kobra.uni-kassel.de/handle/123456789/11591. Accessed 8 Aug 2020.

Bundesregierung (2017, April 21). Antwort der Bundesregierung auf die Kleine Anfrage der Abgeordneten Harald Ebner, Kai Gehring, Friedrich Ostendorff, weiterer Abgeordneter und der Fraktion Bündnis 90/DIE GRÜNEN: Weiterentwicklung der „Nationalen Forschungsstrategie Bioökonomie 2030“. Deutscher Bundestag, 18. Wahlperiode, Drucksache 18/12024. http://dipbt.bundestag.de/doc/btd/18/120/1812024.pdf. Accessed 5 Nov 2020 . 
DUH (2018). Protokoll Netzwerktreffen Bioökonomie, 28 Nov 2018, Berlin. Nicht veröffentlichtes Dokument.

Elmhirst, R., Siscawati, M., Sijapati Basnett, B., \& Ekowati, D. (2017). Gender and Generation in Engagements with Oil Palm in East Kalimantan, Indonesia: Insights from Feminist Political Ecology. The Journal of Peasant Studies, 44(6), 1135-1157.

EU (2007). En Route to the Knowledge-Based Bio-Economy. Brussels. https:// dechema.de/dechema_media/Downloads/Positionspapiere/Cologne_Paper. pdf. Accessed 5 Nov 2020.

Evia Bertullo, V. (2018). Saberes y Experiencias sobre la Exposición a Plaguicidas entre Mujeres que Residen en Contextos Agrícolas en Soriano, Uruguay. Revista TRAMA, 9(9), 13-35.

FNR (2019). Bioenergy in Germany. Facts and Figures 2019. http://www. fnr.de/fileadmin/allgemein/pdf/broschueren/broschuere_basisdaten_bioene rgie_2018_engl_neu.pdf. Accessed 20 Jan 2020.

Fraunhofer ISI (2017). Evaluation der „Nationalen Forschungsstrategie BioÖkonomie 2030“. Wirksamkeit der Initiativen des BMBF - Erfolg der geförderten Vorhaben - Empfehlungen zur strategischen Weiterentwicklung. https://www.isi.fraunhofer.de/content/dam/isi/dokumente/cct/ 2017/Evaluation_NFSB_Abschlussbericht.pdf. Accessed 14 April 2019.

Frickel, S., Gibbon, S., Howard, J., Kempner, J., Ottinger, G., \& Hess, D. (2010). Undone Science: Charting Social Movement and Civil Society Challenges to Research Agenda Setting. Science, Technology, \& Human Values, 35(4), 444-473.

German Bioeconomy Council (2016). Recommendations of the German Bioeconomy Council. Further Development of the "National Research Strategy BioEconomy 2030". Berlin. https://www.biooekonomierat.de/fileadmin/Publik ationen/Englisch/BOER_Empfehlungspapier_ENG_final.pdf. Accessed 23 Nov 2020.

Giurca, A. (2018). Unpacking the Network Discourse: Actors and Storylines in Germany's Wood-Based Bioeconomy. Forest Policy and Economics, 110.

Goven, J., \& Pavone, V. (2014). The Bioeconomy as Political Project: A Polanyian Analysis. Science, Technology, \& Human Values, 40(3), 302-337.

Görg, C. (2004). The Construction of Societal Relationships with Nature. Poiesis \& Praxis, 3(1), 22-36.

Grefe, C. (2016). Global Gardening. Bioökonomie - Neuer Raubbau oder Wirtschaftsform der Zukunft? München: Verlag Antje Kunstmann. 
Haas, T. (2017). Die politische Ökonomie der Energiewende. Deutschland und Spanien im Kontext multipler Krisendynamiken in Europa. Wiesbaden: Springer VS.

Healy, N., \& Barry, J. (2017). Politicizing Energy Justice and Energy System Transitions: Fossil Fuel Divestment and a "Just Transition". Energy Policy, 108, 451-459.

Hess, D.J., \& McKane, R.G. (2017). Renewable Energy Research and Development. A Political Economy Perspective. In D. Tyfield, R. Lave, S. Randalls \& C. Thorpe (Eds.), The Routledge Handbook of the Political Economy of Science (pp. 275-288). London, New York: Routledge.

Hirschl, B., Aretz, A., Prahl, A., Böther, T., Heinbach, K., Pick, D., et al. (2010). Kommunale Wertschöpfung durch erneuerbare Energien. Schriftenreihe des IÖW 196/10. https://www.ioew.de/uploads/tx_uki oewdb/IOEW_SR_196_Kommunale_Wertsch\%C3\%B6pfung_durch_E rneuerbare_Energien.pdf. Accessed 17 June 2020.

Huber, M. (2015). Energy and Social Power. From Political Ecology to the Ecology of Politics. In T. Perreault, G. Bridge \& J. McCarthy (Eds.), The Routledge Handbook of Political Ecology (pp. 481-492). Abingdon, New York: Routledge.

Jenkins, K., McCauley, D., Heffron, R., Stephan, H., \& Rehner, R. (2016). Energy Justice: A Conceptual Review. Energy Research \& Social Science, 11, 174-182.

Kahla, F. (2018). Das Phänomen Bürgerenergie in Deutschland. Eine betriebswirtschaftliche Analyse von Bürgergesellschaften im Bereich der Erneuerbaren Energien-Produktion. Lüneburg: Leuphana Universität Lüneburg. https://pub-data.leuphana.de/frontdoor/deliver/index/docId/ 848/file/Dissertation_Kahla.pdf. Accessed 17 June 2020.

Kleinschmit, D., Arts, B., Giurca, A., Mustalahti, I., Sergent, A., \& Pülzl, H. (2017). Environmental Concerns in Political Bioeconomy Discourses. International Forestry Review, 19(1), 1-15.

Kunze, C. (2012). Soziologie der Energiewende: Erneuerbare Energien und die Transition des ländlichen Raums. Stuttgart: ibidem-Verlag.

Levidow, L., Birch, K., \& Papaioannou, T. (2012). Divergent Paradigms of European Agro-Food Innovation: The Knowledge-Based Bio-Economy (KBBE) as an R\&D Agenda. Science, Technology, \& Human Values, 38(1), 94-125.

Lewandowski, I. (2015). Securing a Sustainable Biomass Supply in a Growing Bioeconomy. Global Food Security, 6, 34-42. 
Lohmann, L., \& Hildyard, N. (2014). Energy, Work and Finance. The Corner House. http://www.thecornerhouse.org.uk/sites/thecornerhouse.org.uk/files/ EnergyWorkFinance\%20\%282.57MB\%29.pdf. Accessed 10 Oct 2019.

Lühmann, M. (2020). Whose European Bioeconomy? Relations of Forces in the Shaping of an Updated EU Bioeconomy Strategy. Environmental Development, 35.

Malm, A. (2016). Fossil Capital. The Rise of Steam Power and the Roots of Global Warming. New York, London: Verso.

Marshall, J. (2014). Solar Energy. Springtime for the Artificial Leaf. Nature. https://www.nature.com/news/solar-energy-springtime-for-the-artifi cial-leaf-1.15341. Accessed 15 May 2019.

Meyer, R. (2017). Bioeconomy Strategies: Contexts, Visions, Guiding Implementation Principles and Resulting Debates. Sustainability, 9(6), 1031.

Miller, C.A., Iles, A., \& Jones, C.F. (2013). The Social Dimension of Energy Transitions. Science as Culture, 22(2), 135-148.

Mitchell, T. (2009). Carbon Democracy. Economy and Society, 38(3), 399-432. Morris, C., \& Jungjohann, A. (2016). Energy Democracy. Germany's Energiewende to Renewables. Houndmills, Basingstoke: Palgrave Macmillan.

Priefer, C., Jörissen, J., \& Frör, O. (2017). Pathways to Shape the Bioeconomy. Resources, 6(1), 10.

Radtke, J. (2016). Bürgerenergie in Deutschland. Partizipation zwischen Gemeinwohl und Rendite. Wiesbaden: Springer VS.

Strzalka, R., Schneider, D., \& Eicker, U. (2017). Current Status of Bioenergy Technologies in Germany. Renewable and Sustainable Energy Reviews, 72, 801-820.

Szarka, N., Eichhorn, M., Kittler, R., Bezama, A., \& Thrän, D. (2017). Interpreting Long-Term Energy Scenarios and the Role of Bioenergy in Germany. Renewable and Sustainable Energy Reviews, 68, 1222-1233.

Szulecki, K. (2018). Conceptualizing Energy Democracy. Environmental Politics, 27(1), 21-41.

Tyfield, D., Lave, R., Randalls, S., \& Thorpe, C. (2017). Introduction: Beyond Crisis in the Knowledge Economy. In D. Tyfield, R. Lave, S. Randalls \& C. Thorpe (Eds.), The Routledge Handbook of the Political Economy of Science (pp. 1-18). London, New York: Routledge.

UBA (2020). Erneuerbare Energien in Deutschland. Daten zur Entwicklung im Jahr 2019. https://www.umweltbundesamt.de/sites/default/files/medien/ 1410/publikationen/2020-04-03_hgp-ee-in-zahlen_bf.pdf. Accessed 3 May 2020. 
Vivien, F.-D., Nieddu, M., Befort, N., Debref, R., \& Giampietro, M. (2019). The Hijacking of the Bioeconomy. Ecological Economics, 159, 189-197. Weis, L., Becker, S., \& Naumann, M. (2015). Energiedemokratie. Grundlage und Perspektive einer kritischen Energieforschung. RosaLuxemburg-Stiftung STUDIEN (01). https://www.rosalux.de/fileadmin/rls_ uploads/pdfs/Studien/Studien_01-15_Energiedemokratie.pdf. Accessed 10 Oct 2019.

Wissen, M. (2016). Jenseits der carbon democracy. Zur Demokratisierung der gesellschaftlichen Naturverhältnisse. In A. Demirović (Ed.), Transformation der Demokratie - demokratische Transformation (pp. 48-66). Münster: Westfälisches Dampfboot.

Zivilgesellschaftliches Aktionsforum Bioökonomie (2019, July 19). Stellungnahme an die Bundesregierung zum Entwurf einer Nationalen Bioökonomiestrategie. https://denkhausbremen.de/wp-content/uploads/ 2019/07/Stellungnahme-Bio\%C3\%B6konomie.pdf. Accessed 14 Nov 2019.

Zivilgesellschaftliche Plattform Forschungswende (2017). Positionspapier zivilgesellschaftliche Plattform Forschungswende: Kernforderungen für das 7. Energieforschungsrahmenprogramm. https://www.energieforschung.de/ lw_resource/datapool/systemfiles/elements/files/6FFE14A82C281782E0 539A695E862C2E/current/document/5_FW_Positionspapier_Energie.pdf. Accessed 4 Oct 2019. 
Open Access This chapter is licensed under the terms of the Creative Commons Attribution 4.0 International License (http://creativecommons.org/ licenses/by/4.0/), which permits use, sharing, adaptation, distribution and reproduction in any medium or format, as long as you give appropriate credit to the original author(s) and the source, provide a link to the Creative Commons license and indicate if changes were made.

The images or other third party material in this chapter are included in the chapter's Creative Commons license, unless indicated otherwise in a credit line to the material. If material is not included in the chapter's Creative Commons license and your intended use is not permitted by statutory regulation or exceeds the permitted use, you will need to obtain permission directly from the copyright holder.

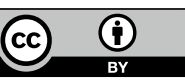

